\title{
Penso de la Vega and the Question of Jewish Baroque
}

\author{
Einat Davidi*
}

Since the second decade of the twentieth century, we have witnessed increasing interest in Baroque writing. However, apart from a few mentions, the concept of Baroque has hardly been applied to the field of Jewish writing, and even less so to the field of Hebrew writing. In this essay, I would like to portray the image of a Jewish Baroque writer by focusing on José Penso de la Vega, ${ }^{1}$ who sophisticatedly represented the Baroque spirit and style in his work. After explicating the concept "Baroque," I will draw a short biobibliography of the author, and then will discuss the Baroque characteristics of three different texts by him. I will conclude by making brief remarks about the prima facie difficulty in characterizing a Jewish writer as a Baroque writer.

\section{$1 \quad$ What is "Baroque"?}

Unlike the term "Renaissance," "Baroque" is not a term employed by contemporaries to designate their epochal innovation or worldview. It is rather an anachronistic term that has been transformed essentially and which underwent modifications of meaning and application. Since my aim is to portray a Jewish Baroque writer, it is necessary to mark the boundaries of this term.

"Baroque" was primarily a pejorative term applied by neo-classical art criticism to seventeenth-century art in order to differentiate this decadent art from Renaissance art. Wölfflin's Renaissance und Barock ${ }^{2}$ marks a change, and for the first time applies the term "Baroque" as a positive attribute. Moreover, this

* The research leading to these results has received funding from the European Research Council under the European Union's Seventh Framework Programme (FP7/2007-2013) / ERC grant agreement $\mathrm{n}^{\circ} 29535^{2}$.

1 The author used different spellings of his name in different occasions and contexts. Besides "Josseph," he also used "José" (in the bibliographical items I used the spellings in the way they appear in Penso's works).

2 Heinrich Wölfflin, Renaissance und Barock: eine Untersuchung über Wesen und Entstehung des Barockstils in Italien (Munich: Theodor Ackermann, 1888).

(C) EINAT DAVIDI, 2019 | DOI:10.1163/9789004392489_020

This is an open access chapter distributed under the terms of the prevailing CC-BY-NC License at the time of publication. 
term began to signify style and to apply not only to art and architecture, but also to literature.

Another crucial turning point was Maravall's La cultura del barroco, ${ }^{3}$ in which "Baroque" is no longer employed as an aesthetic term, but rather as a cultural and historical one-Maravall analyzes Baroque culture in the socioeconomic context of the seventeenth century. This development in the history of the term "Baroque" is ultimately responsible for the use of this term from that moment onwards as a designator of an epoch and a culture. Despite the enormous contribution of this work to the conceptualization of Baroque as a broad cultural phenomenon, it tends to shift the importance attributed to this phenomenon from theology (and especially Counter-Reformation) to the fields of economics and sociology.

In recent decades, we have witnessed a new tendency that emphasizes the socio-religious and theologico-religious conditioning of Baroque as both a worldview and a style. This tendency has emerged not only out of dissatisfaction with Maravall's socio-economic view, but was also inspired by Walter Benjamin's pan-European analysis of Baroque in Ursprung des deutschen Trauerspiels (1928), ${ }^{4}$ with whose interpretation we are still debating. Benjamin analyzes the interaction of secularism and metaphysics in seventeenthcentury allegory, as well as the origin of allegoric theater-the most prominent public art form of seventeenth-century society. The Baroque is a problematic era dominated by a pessimistic secular "modern" view that conceives of history as a process of permanent decay. ${ }^{5}$ Still, there is a desire to overcome melancholy and to return to the harmonic medieval calm, to ordo. In order to reconcile these contradictory tendencies, it was necessary to revive Christian allegory; in other words, to provide a moral interpretation of physical and cultural phenomena in light of their divine origin and hidden spiritual meaning. The internal logic of Baroque is an allegoric transfiguration of reality. The Baroque allegory is an answer to the conflict between the Middle Ages and modernity. ${ }^{6}$

Benjamin's book has been warmly adopted by post-modernist and poststructuralist thinkers. ${ }^{7}$ Moreover, the French neo-Nietzschean philosophical

3 José Antonio Maravall, La cultura del barroco: análisis de una estructura histórica (Barcelona: Ariel, 1975).

4 Walter Benjamin, "Ursprung des Deutschen Trauerspiels" in Gesammelte Schriften, ed. Rolf Tiedemann and Hermann Schweppenhäuser (Frankfurt/Main: Suhrkamp, 1974), 1: 203-431.

5 Ibid., 353 .

6 Ibid., 403 .

7 Benjamin's influence is conspicuous in Baudrillard's theory of simulacrum, see Jean Baudrillard, L'Echange Symbolique et la mort (Paris: Gallimard, 1976), and Gilles Deleuze, The 
school began to use the term "Baroque" in the context of anti-rationalistic criticism, and in order to argue against features of modern rationality such as "representation" and "origin." These scholars contributed immensely to the mapping of Baroque aesthetics, but unlike Benjamin they dealt with Baroque without any historical context. This treatment of Baroque is possibly responsible for the fact that those thinkers ignored, perhaps deliberately, an essential difference between their analysis and the historical spirit of Baroque, which is inextricably linked to the Counter-Reformation. Whereas the neo-Nietzschean philosophical school denies the priority and even the very existence of origin and truth, Baroque inherited the substantialism of the Middle Ages.

According to Benjamin, the immediate threat to Christianity is represented by secularism and paganism, to which the Renaissance gave birth. The Baroque allegory is a reactionary instrument born out of the theological crisis of that epoch. Baroque allegory opposes synthesis and coherence. However, as Kluge explains, the transformation of the historical world into a graceless state of sin and the emphasis on the ephemeral nature of earthly reality form only the first step in the dialectic processes on the way to salvation, a way of revealing the illusionary nature of renaissance vitality, of its earthly hedonistic vitality. Only by affirming the gap between history and grace, and by finally representing it as temporary or illusionary, does the Baroque allegory triumph over the non-transcendent worldview, which it opposes, and integrate it into a restitutive Christian universe. ${ }^{8}$ The Baroque allegory is, therefore, a Christian art that incorporates and transfigures the non-transcendent worldview it opposes. ${ }^{9}$

For that reason, Baroque art is an art of contrasts: secularism and spiritual religion; immanence and transcendence; anthropomorphism and theocentrism; asceticism and hedonism. Thus, theater is the overarching allegory of the Baroque worldview and, consequently, the basic dialectic procedure of Baroque art: engaño y desengaño, masks, hiding, and falsification. Truth is hidden, and hence the genres and subgenres of riddles and emblems are so prominent. Reflections, duplication, mirrors, and the question of simulacrum is always present; bewilderedness as to what is original and what is reflection; this epistemic oscillation is at the very core of Baroque art, but it is always only a phase on the way to the revelation of origin and truth.

Fold: Leibniz and the Baroque (Minneapolis: University of Minnesota Press, 1993). See also, Christine Buci-Glucksmann, La Raison Baroque. De Baudelaire à Benjamin (Paris: Galilée, 1984).

8 See Sofie Kluge, Baroque, Allegory, Comedia. The Transfiguration of Tragedy in SeventeenthCentury Spain (Kassel: Reichenberger, 2010), 22.

9 Benjamin, Ursprung des Deutschen Trauerspiels, 259, 390. 
I will now draw the profile of a Jewish writer who, in my opinion, incorporates more than any other Jewish writer what could be denominated as "Jewish Baroque." José Penso de la Vega was probably born in Hamburg around 1650. He moved to Amsterdam as a child with his family in $1656{ }^{10}$ His father Isaac Penso, born in Espejo, Córdoba, had been imprisoned in inquisitorial jail and had taken an oath to declare himself openly as a Jew were he released. After his release, he arrived at Middelburg, where he reconverted to Judaism and became a pious Jew. He continued to Amsterdam, and then to Hamburg, where he married and his older children, José among them, were probably born. In Amsterdam, he became a very successful merchant and one of the most generous donors of the community. José Penso was educated in the Ets Haim yeshiva, in which he learned Hebrew, the Bible, and Jewish classical biblical exegesis.

At an early age, he composed two texts in Hebrew. The first text is a maqama - a rhymed prose, a series of allegories (meshalim in Hebrew) - in which the polemic theme is prominent. The second text is a drama called Prisoners of Hope (Asire ha-Tikva). I have argued elsewhere ${ }^{11}$ that this drama is in fact an auto-sacramental. This dramatic allegorical genre, a genuine Spanish one, is closely related to the Counter-Reformation. As I show there, Prisoners of Hope is the first auto sacramental work in Hebrew. It is also the first dramatic Hebrew play ever printed: the dramatic genre hardly existed in the Jewish world prior to the seventeenth century. This dramatic work was praised and glorified by the community's prominent leaders and rabbis, and its poets. The rich and extended paratext is a testimony to this admiration. In this oeuvre, the young writer demonstrates his phenomenal knowledge of the Hebrew language and Hebrew sources. Moreover, this work is also a didactic book with moral lessons aimed at the young generation. Thus, it appears that the eloquent Penso paved his way to a career as a preacher and perhaps to a rabbinical career. But life took a different course.

\footnotetext{
10 From 1665 onward, the name Isaac Penso begins to appear regularly in the communal records of the Amsterdam congregation, in the list of the community's taxpayers. The single appearance of his name in $165^{\circ}$ is probably the reason for the assumption that he had settled there by this year. The claim, which appears often in scholarship, that José Penso was born in Espejo, Córdoba, like his father, is implausible, since his father was married after leaving Spain. His mother's death certificate attests to this since according to it she had married in Hamburg.

Einat Davidi, "The Corpus of the Hebrew and Jewish Autos Sacramentales," forthcoming.
} 
At that point, Penso left Amsterdam for Livorno. The information concerning his life there is scarce; there is speculation that he was involved in maritime trade. ${ }^{12}$ Additionally, Penso did not publish anything during that period. However, we have a letter sent by Penso from Livorno to Orobio de Castro, in which he asks him for support to establish a literary academy there. ${ }^{13} \mathrm{We}$ may thus learn something about this period in his life indirectly, from later events. In 1683, immediately after the death of his father, Penso returned to Amsterdam, where he resided until his own death. ${ }^{14}$ During the year of his return, he published a series of manuscripts, but it is highly improbable that these texts were written in that year. Among these texts are a collection of sermons and three short novels. It seems plausible to infer that Penso composed them during his Italian years and only published them in Amsterdam. It is left to speculate whether he published these works in Amsterdam because it was much easier for him to do so in his home community, or since he did not wish to publish his Italian works out of respect for his pious father-after all, many of these works possessed a mundane Renaissance flavor and utilized Roman mythology. These characteristics form part of the references, examples, and metaphors in all the texts, but this holds especially true in the short novel. This (at the time) new, humanistic genre—the short novel—which was identified with Renaissance mundanity, played an entertaining role rather than having any spiritual, didactic, or moral function. All these texts by Penso were written in Spanish, and apart from a couple of early Hebrew texts, Penso never wrote again in Hebrew.

In the years that followed, Penso's life took another turn. He perhaps quit his literary activity for a while and dedicated himself to the financial world. In the year 1688, he published his famous book Confusion of Confusions, and in 1692, he published a collection of twelve rewritings of biblical stories (re-écriture); four texts in this collection are not his own but are translations of Italian pieces. Penso passed away in Amsterdam in 1692.

\footnotetext{
12 Valentina Nider, "José Penso e l'accademia sefardita 'de los sitibundos' di Livorno nella diffusione di un genere oratorio fra Italia e Spagna: Traduzione e limitazione nelle 'Ideas posibles' (1692)," Studi secenteschi 51 (2010): 156-57.

13 Letter from Penso in Miguel de Barrios, Respuesta Panegírica (Amsterdam, 1677).

14 Penso's name is absent in the community's tax records until 17 September, 1683, a few months after his father's death. From this point onward, his name appears regularly in the records until his death.
} 


\section{Baroque Characteristics in Three Works by Penso de la Vega}

I will now show how the Baroque culture and worldview are embodied in three works by Penso. The first, the book that turned out to be Penso's most famous work-Confusion of Confusions (Confusión de confusiones) - is a text with an original structure on an original subject matter. The second is a short novel, and the third is a work of a genuine Spanish Baroque genre: an auto sacramental.

The book Confusion of Confusions was about a never-before written theme: the stock exchange. ${ }^{15}$ This book provoked the interest of economic historians, ${ }^{16}$ and is even considered "an essential reference work in the history of stock markets and even of current financial operations." ${ }^{17}$ It was translated into Dutch, German, and English, and was one of the few historical sources (if not the only one) on the collapse of the Amsterdam stock market in $1688 .{ }^{18}$ It became Penso's most well-known book, and "the most innovative contribution of José de la Vega to universal culture,"19 but was not considered an expression of a Baroque worldview. However, I will argue that there are good reasons to consider it as such.

The text consists in a dialogue between an investor, a merchant, and a philosopher, in which the well-experienced and knowledgeable investor helps his interlocutors to understand the principles of the market. The philosopher seeks to understand the business of the stock exchange and gives in to the temptation to invest in it. He soon becomes the victim of a conspiracy by investors and, in the end, decides to quit. The merchant also seeks to learn about

15 According to Torrente Fortuño, there are six known copies of the book: in the Ets Haim library in Amsterdam, in the National Library in The Hague, in the University Library of Göttingen, in the University Library of Aquisgrán, in the Library of the British Museum in London, and in the National Library in Madrid. See Torrente Fortunio, La bolsa en José de la Vega. Confusion de Confusiones-Amsterdam 1686 (Madrid: Libropolis, 1980).

16 Richard Ehrenberg, Das Zeitalter der Fugger (Hildesheim: Georg Olms Verlagsbuchhandlung, 1963 [Jena, 1896]); Werner Sombart, Die Juden und das Wirtschaftsleben (Leipzig: Verlag von Duncker und Humblot, 1911).

17 José Luís Cardoso, "Confusion de confusions: ethics and options on seventeenth-century stock exchange markets," Financial History Review 9, no. 2 (2002): 114.

18 Jonathan Israel, "Een merkwaardig literair werk en de Amsterdamse effectenmarkt in 1688. Joseph Penso de la Vega, Confusión de confusiones," De Zeventiende eeuw 6 (1990): 159-165; Hermann Kellenbenz's introduction to the English 1957 edition. Penso de la Vega, Confusion of Confusion. Portions Descriptive of the Amsterdam Stock Exchange (Cambridge, MA: Baker Library, Harvard Graduate School of Business Administration, 1957); José Cardoso, "Confusión de confusiones: Ethics and Options on Seventeenth-Century Stock Exchange Markets," Financial History Review 9, no. 2 (2002): 109-23.

19 Fortuño, La bolsa en José de la Vega, 283 (translation mine). 
the purchase of trade company shares in order to increase his gains, and after a failed attempt, he too decides to quit.

This dialogue is an allegorical transfiguration of the reality of the stock market. It is dominated by the idea of the world as a stock market game. Baroque texts frequently include such allegories: the idea of the world as a "labyrinth," the idea of the world as a "roadhouse," and the idea of "life as a dream" are found in many texts of the seventeenth century and are used frequently by Baroque writers and philosophers. Penso adds to these allegories one about the stock market. The book Confusion of Confusions is a satirical dialogue about the stock exchange, which serves as an allegory for human existence. The stock exchange exposes essential elements of reality and human nature. According to Penso, "[t]here is no better hieroglyph of this world but the shares." ${ }^{20}$ Through a synecdoche of the stock market, Penso describes human life and human reality as he views them: first and foremost, he highlights the uncertainty, instability, and permanent changing as essential characteristics of human reality. Human life is characterized by the need to make decisions under conditions of uncertainty, and the helplessness that results from it. Secondly, he elaborates upon the idea of Homo homini lupus - the combative and militant character of human beings - an idea known to him not only from Hobbes but also from Balthasar Gracián's Criticón. Finally, he portrays the stock market as an embodiment of the idea of versatile, opportunistic morality, indifferent to imperatives of religion, integrity, and honor.

The Baroque man is not equipped with a coherent Weltanschauung that serves as a moral compass. He uses adaptive strategies according to everchanging situations at every single moment. Since there is no longer any confidence, faith, or certainty, and the essence of things is not accessible, appearance is the most that we can grasp. He who manages to learn the rules of the game could win the struggle for existence. This idea stands behind the pragmatic and adaptive spirit of this book. The stock market itself is thus portrayed as a microcosm - it is an allegory of the world, and the investor's behavior serves as an allegory for human behavior.

For economic historians, this text might serve as a single document concerning certain historical events - a historical document of a unique type and

20 "[...] no puedo haber mejor geroglífico de las Acciones, que este mundo." Confusión de confusiones Diálogos Curiosos entre un Philósopho agudo, un Mercader discreto, y un Accionista erudito descriviendo el negocio de las Acciones, su origen, su ethimología, su realidad, su juego y su enredo, Compuesto por Don Iosseph de la Vega, Que con reverente obsequio lo dedica al Mérito y Curiosidad del muy Ilustre Señor Duarte Nuñez da Costa. Én Amsterdam Año 1688. This citation and all the others citations that follow are from a copied edition of the original book, published by Ediciones Saetabis, 1977. 
style. However, Penso, whose words are put in the investor's mouth, justifies his choice of this original and bizarre subject in a different way. Penso mentions Latin medieval authors who devoted works in praise of lice or fleas, and claims that it is just as legitimate for him to write about the stock market and the human behavior it exhibits. ${ }^{21}$ For Penso, the legitimacy of writing about such a prosaic, mundane, and "low" subject is mainly rooted in its value as an allegory.

However, the allegorical transfiguration of the realm of the stock exchange is certainly not the only Baroque aspect of Penso's book. For Penso, with his Baroque sensitivity, the collapse of the stock market in 1688 appeared as an allegory—as a moment of desengaño, a disillusionary event: this historic event perfectly coincides with the aesthetic dialectic of the Baroque. In August 1688, rumors spread about an upcoming war. Panic ensued among investors, and most of them rushed to sell their "ducatón" shares. The market collapsed within one day, "like the statue of Nebuchadnezzar, all at once."22 Penso maintains that the fear of an impending war was the cause of the fall of the East Indian Company.

The rumors of a possible war spread when William the Stadtholder, Prince of Orange, began to reinforce his military navy. It caused a dramatic fall in the price of shares and then panic. However, from September 5 th, when the fog cleared and there was no doubt that William was going to invade England and that France was going to declare a war, experienced and serious investors began to buy shares again, and the remaining investors followed suit. Then the "bulls" and "patriots," as Penso refers to those investors, gained the upper hand and managed to change the market's tendencies precisely at a time when the purpose of the Dutch navy's rearrangement and the enormous risks to which it was exposed had already become evident. Shares of the East Indian Company rose although everybody knew about the upcoming war. Investors took great risk in buying shares of the Dutch company during times of war. Those who gambled on William's success by lending him great amounts of money stood to lose a lot. Still, this act was an expression of their trust in the Republic and its military in this critical hour, a short time before the invasion of England. At last, William of Orange's success, the dethroning of his father-in-law, James II, and the occupation of England, Ireland, and Scotland justified the trust given

21 “Tejió el Calcañino un panegírico a la pulga intitulado 'Encomium Pulicis,' el Luciano una loa a la mosca 'De Musca,' el Melanton un loor a la Hormiga, 'De Laudibus formiga,' el dousa un elogio a la sombra 'In Laudem umbra,' el Bilibaldo un encomio a la Gora 'De Laudibus podagra,' mereciendo por laurel el tema y por premio el asunto. Y todas estas plumas hubieran rendido sus obsequios a mis meditaciones si profesasen el negocio que describe y lezesen lo que pondero sobre el negocio." Penso de la Vega, Confusión, 112. “[...] como la estatua de Nabuco, toda de un golpe." Ibid., 378. 
to him by the patriots and the risk they took. When the crisis was over, shares went up gradually until the end of the year.

Penso started writing the book before the crisis and the collapse. His idea was to allegorize the stock market's reality - to present it as an allegory for the zeitgeist and human behavior. Furthermore, the collapse that he witnessed and documented in his book coincided with the Baroque aesthetic model of illusion and disillusion. The market's sudden crash, which created a psychological atmosphere of disillusionment, inspired the Baroque writer. It was most suitable for exposing the relation between things and their reflection, reality and appearance, man and mask. Deception and self-deception rules everywhere. What had seemed to be a goldmine until August 1688 was revealed within one day to be a tragedy that brought many people to bankruptcy. The collapse of the stock market exposed the illusion of the masses seeking fortune and easy gains.

Symbolically, the philosopher quits the world of the stock exchange after giving a short sermon following his disillusionment and leaves the arena to others. The viewpoint of the philosopher after the disillusion is a moral, ascetic one that denounces passion and endorses the human ideal of temperance. Passion is the origin of the pursuit of easy gains and of a pretentious lifestyle of indulgence and pleasures. It leads to reckless greediness. In order to overcome "confusion," it is necessary to strive for solid and definite aims. The philosopher views passion and obsessive pursuit from the perspective of death and the redemption of the soul. In this way, ascetic ideals and substantialism are manifested. These ideals are the medieval heritage within Baroque culture. Penso, who received a Jewish education in the Ets Haim yeshiva, here expresses a religious attitude. More than being a Jewish or Christian one, it is a medieval one. The philosopher is an old man, wise and learned, a man of the old scholastic order, who has no tools to grasp the new reality, allegorized as the stock exchange.

Penso's collection of short novels Dangerous Paths (Rumbos Peligrosos) was written either during his Italian years or shortly thereafter. ${ }^{23}$ The short novel was at that time a relatively new genre, born in the Italian Renaissance and adopted in Spain by Cervantes, Lope de Vega, and other authors. ${ }^{24}$ Like Cervantes and Lope, Penso gave a Baroque flavor to the through-and-through

23 Regarding the period of the novel's composition, see a discussion by José Fradejas Lebrero, "José de la Vega, novelista cortesano," in Los judaizantes en Europa y la literatura castellana del Siglo de Oro, ed. Fernando Díaz Esteban (Madrid: Letrúmero, 1994), 161.

24 On the adaptation of the short novel by Spanish authors, see David González Ramírez, "En el origen de la novella corta del Siglo de Oro: los novellieri en España," ARBOR Ciencia, Pensamiento y Cultura 187-752 (2011): 1221-43. 
secular genre, but he certainly did it to a much greater extent than those authors-especially with the presumptuous and innovative combination of different genres, but also by combining riddles, enigmas, and homiletic interpretations of names, and by creating a plot consisting in the theatrical game of identity. The story takes place in a Baroque salon sphere, in the elitist and hedonistic leisure culture. Using one of the epoch's secular genres, Penso, who grew up in an observant atmosphere, manifests here the mundane pole of his writing.

In Penso's first short novel, "Delicacy of Friendship and Triumph of the Innocence" ("Fineza de la amistad y triunfo de la inocencia"), Clorinda, a young lady who received a marriage promise in Seville, comes to Naples to look for her fiancé, whose identity is not known to her since she met him in darkness. She finds shelter in the house of Felisberto and his sisters. In a mysterious moment, Felisberto sees the reflection of Clorinda's face in a mirror left in his garden. He is puzzled by her similarity to a woman to whom he himself gave a marriage promise. From that moment on, the novel develops as a game of masks, duplications, reflections, and a confusion of identities. The telos is the disclosure of true identity, as if the classical anagnorisis is here being elevated to a major aesthetic principle and is perpetuated, since there are quickly four masculine and four feminine figures trying to determine who is who and who belongs to whom.

As Fernando Copello showed convincingly, the novel's dominant characteristic is its eclectic hybridity. Penso himself is aware of this aesthetic, and in the introduction to the novels he refers to their style, denominating them "works of jasper, as the Athenians called that to which they 'sprinkled' with different shades and changing concepts; rising now in the News, now in the Sweet, now in the Rhetorical, now in the Fabulous, and now in the Jocund." ${ }^{25}$ The novel reflects a chaotic universe, incoherent and inconsistent, and expresses an unstable and dynamic worldview. It combines poetry, letters, riddles, and even brief sermons in an intergeneric ludic modus, ${ }^{26}$ a sort of genre experimentalism more typical of the twentieth century than of the seventeenth.

A second Baroque feature of the text is its multiplicity of mysterious elements, of the unknown and the hidden, as the force underlying the plot. The

25 “[...] obras de jaspe, como intitulaban los Atenienses a las que salpicaban con diferentes matices y cambiantes sus conceptos; elevándose ya en lo Noticioso, ya en lo Dulce, ya en lo Retórico, ya en lo Fabuloso y ya en lo Jocundo." Penso de la Vega, Rumbos peligrosos, xviii (translation mine).

26 Fernando Copello, "Hibridismo y variedad en una novella corta de Joseph Penso de la Vega y Miguel de Barrios: Fineza de la Amistad y triunfo de la inocencia ( $i$-Amsterdam? 1683)," Mélanges de la Casa de Velázquez 43, no. 2 (2013): 119-37. 
dynamics of concealment and disclosure is not a serious dialectic, but rather a ludic, theatrically entertaining, and pleasant game. The riddle was a prominent genre in the Baroque era that was highly refined and developed among Jewish writers in Italy and Holland in the seventeenth century. ${ }^{27}$ Penso himself was a composer and solver of some well-documented riddles. ${ }^{28}$ Many riddles are embedded in the novel, sometimes with possible solutions. For example, a question is raised about the meaning of the enigmatic initials "A.F." which appear as the name of the letters' mysterious writer. There are many possible solutions: is it an abbreviation of "love and fortune" (amory fortuna), or "fine love" (amor fino), or "furious Alexander" (Alejandro furioso), or perhaps "fine friendship" (Amistad fina), which is the novel's title?

The riddle is a genre that has a lot in common with theater: their common denominator is the dialectic of concealment and disclosure. But it is also a certain kind of game: the game characterizes not only the writing mode, or the combination of genres, but rather takes up a great part of the plot. When Felisberto finds himself in his salon in the company of four ladies, they discuss how they should pass their time: in comedy, music, dance, or with a game. Afterwards, they consider which game they should play, and conduct a theoretical discussion about different games (chess, backgammon, checkers, cards) and their principles and symbolic value. This reflective discussion about the game as allegory of reality and of society in particular is unprecedented in the history of literature. This discussion represents game theory, but it is also an allegory for the social game (social functions, social strata, and even gender). Furthermore, it is also an allegory of the rhetorical game: it has an auto-poetic dimension.

It is thus not surprising that the game chosen to be played is a card game. Its distinguishing feature is exactly the dynamics of concealment and disclosure. Every player sees his own card but not the others, and during play there are strategies of disclosure. But "carta" in Spanish is a polysemic word that means also "letter." As mentioned, the novel includes several mysterious letters written in a cryptic style. The parlor game thus functions as an allegory of the plot itself, the novel, in which "cards" are concealed and disclosed. This is the game's auto-poetic function. ${ }^{29}$

27 Dan Pagis, A Secret Sealed. Hebrew Baroque Emblem-Riddles from Italy and Holland (Jerusalem: Magnes Press, 1986) [Hebrew].

28 Ibid., 25, 48, 84 .

29 The game of fraud and concealment takes place not only in the text but also in the paratext, which is of course about reality and not a game. The place of publication appears as Brussels, but Den Boer has demonstrated convincingly that the novels were published in Amsterdam. He raises the conjecture that Penso wished to conceal his Jewish identity 
It is therefore only natural that the novel ends with a big masquerade ball, in which the truth is finally disclosed. All riddles meet their solutions, everyone's true identity is exposed, and the entire chaos is brought into order. Similar to Shakespeare's pastoral comedy As You Like It, the eight figures are coupled miraculously into four happy pairs to everyone's satisfaction. As in Confusion of Confusions, the text ends with a colossal, dramatic desengaño and, again, Baroque's substantialist character comes to light.

Nonetheless, the most obvious expression of Penso de la Vega's Baroque worldview and Baroque literary profile is definitely the auto sacramental drama entitled Asirei ha-Tikva (Prisoners of Hope), which he wrote in his youth, and which by itself may grant Penso the title of "the Jewish Baroque writer par excellence." This text, published in $1668,{ }^{30}$ and again in Livorno in $1771,{ }^{31}$ is the first auto sacramental in Hebrew. ${ }^{32}$ Miguel de Barrios would later write a dramatic work with a strong auto sacramental character, ${ }^{33}$ yet Penso's drama, unlike de Barrios's, employs pure allegories-prosopopea, the personification of abstract concepts. Furthermore, the constellation of his figures is much more Calderonian and actually is quite similar to that of Calderón's paradigmatic auto sacramental, La vida es sueño.

As Poppenberg showed, in the paradigmatic auto sacramental plot, there is a special dialectic between the representatives of good and evil that fight over control of the human soul. This is basically a medieval dramatic structure that is known mostly from "Everyman" and similar pieces, and was modified in Siglo de Oro literature. In the midst of the drama, evil gains the upper hand. In this part, fraud, falsification, and disguise are involved: evil disguises itself as good, Satan is disguised as an angel, passion is disguised as reason, etc. ${ }^{34}$ This structure is almost the quintessence of the Baroque dialectic, which is

in order to gain a Spanish non-Jewish audience, to whom this kind of mundane text is addressed. (Harm den Boer, "Ediciones falsificadas de Holanda en el siglo XVII: escritores sefarditas y censura Judaica," in Varia bibliographica. Homenaje a José Simón Díaz [Kassel: Casado Lobato, 1987], 99-104.) Another possible reason for this concealment is that he wanted to avoid censorship by the community's board of governors (Mahamad).

$30 \quad$ Josseph Penso, Pardes Shoshanim (Amsterdam, 1668).

31 Josseph Penso, Asirei ha-Tikva (Livorno, 1771).

32 On Penso's auto sacramental in the context of this genre in Jewish space, see Einat Davidi, "The Corpus of Hebrew and Jewish Autos Sacramentales: Self-Deception and Conversion," European Journal of Jewish Studies 13, no. 2 (2019) (forthcoming).

33 The play Contra la Verdad no hay Fuerza was reprinted by Kenneth R. Scholberg, La poesía religiosa de Miguel de Barrios (Madrid: Ohio State University Press, 1962).

34 For an extensive discussion of the auto sacramental genre in its theological context, see Gerhard Poppenberg, Psyche und Allegorie. Studien zum spanischen auto sacramental von den Anfängen bis zu Calderón (Paderborn: Fink, 2003). 
basically a strategy of delay, the temporary appearance of the lie, engaño, until finally desengaño happens and the divine truth is revealed.

In Prisoners of Hope, the representative of evil is indeed "Satan" and he is accompanied and assisted by "Desire," "Pleasure," and "Woman," while the representative of good is "Reason" (Sekhel), assisted by "Providence," "Truth," and an "Angel." The prologue of the play connects "Reason" with a man of the community's older generation, while "Satan" is associated with a young man. But in this introduction "Satan" is also associated with Christianity, so implicitly "Reason" is also associated with Judaism. Both the constellation of characters and the structure of the plot are typical characteristics of auto sacramental. In this didactic work, the Jewish truth is revealed after being temporarily concealed in a typical Baroque desengaño.

\section{$4 \quad$ Conclusions}

Especially while taking into consideration the Baroque's Counter-Reformation theological background, it would seem that there is a prima facie difficulty in characterizing a Jewish writer as a Baroque writer. Nevertheless, the reading of texts by writers such as Penso de la Vega - that is, New Jews or their descendants - in light of their background of reconversion, gives rise to two observations.

First, as members in communities of New Jews (or their descendants) who lived in Spain and sometimes in Italy during the period of the CounterReformation, these people-despite their multifaceted identity-naturally absorbed the Baroque worldview, whose clearest expression, as Benjamin maintains, is allegorical theater. Thus, after they left Iberia, they became its emissaries and even disseminators in northern Europe. ${ }^{35}$

Second, and more importantly, it is precisely the experience of re-conversion - this specific historical experience of living in Iberia as New Christians and returning to Judaism during the seventeenth century-that coincides with the narrative of illusion and disillusion, concealment and revelation, engaño and desengaño. This experience coincides well with the dialectic process on the way to salvation, which constitutes the very essence of the Baroque worldview. In this paper, I attempted to show the deep extent

35 On the role of Amsterdam Jews in the transmission of Calderón's theater in the Northern countries see Henry W. Sullivan, Calderón in the German Lands and the Low Countries: His Reception and Influence, 1654-1980 (Cambridge: Cambridge University Press, 2009), 62-65. 
to which this characterizes Penso's work, and thus that he is, in a significant sense, a Jewish Baroque writer.

The issues, on the one hand, of Spain as a radiating center of Baroque (as highlighted mainly by Benjamin) and, on the other hand, the affinity between Baroque's dialectic structure and the structure of narrative and historical experience of reconverted Jews and their descendants from the Western Sephardic diaspora, shed light on the question of Jewish Baroque, as well as on the old discussion about the beginnings and origins of early modern Hebrew literature and the question of Sephardic Jews' contribution to it in comparison with that of Italian-Jewish writers. The case of Penso de la Vega is a prominent example of how the specific historical experience not only enabled the creation of Jewish Baroque as both a worldview and style, but intensified it.

\section{Bibliography}

Barrios, Miguel de. Respuesta Panegírica. Amsterdam: Jacob van Velsen, 1677.

Baudrillard, Jean. L'Echange Symbolique et la mort. Paris: Gallimar, 1976.

Benjamin, Walter. "Ursprung des Deutschen Trauerspiels." In Gesammelte Schriften. 7 Vols. Edited by Rolf Tiedemann and Hermann Schweppenhauser, 1: 203-431. Frankfurt/Main: Suhrkamp, 1974.

Buci-Glucksmann, Christine. La Raison baroque. De Baudelaire à Benjamin. Paris: Galilée, 1984.

Cardoso, José Luís. "Confusión de Confusiones: Ethics and Options on SeventeenthCentury Stock Exchange Markets." Financial History Review 9, no. 2 (2002):109-23.

Copello, Fernando. "Hibridismo y variedad en una novella corta de Joseph Penso de la Vega y Miguel de Barrios: Fineza de la Amistad y triunfo de la inocencia (¿-Amsterdam?, 1683)." Mélanges de la Casa de Velázquez 43, no. 2 (2013): 119-37.

Davidi, Einat. "The Corpus of the Hebrew and Jewish Autos Sacramentales," European Journal of Jewish Studies 13, no. 2 (2019) (forthcoming).

Deleuze, Gilles. The Fold: Leibniz and the Baroque. Minneapolis: University of Minnesota Press, 1993.

Ehrenberg, Richard. Das Zeitalter der Fugger [The Age of the Fuggers]. Jena, 1896; Hildesheim: Georg Olms Verlagsbuchhandlung, 1963.

Den Boer, Harm. "Ediciones falsificadas de Holanda en el siglo XVII: escritores sefarditas y censura Judaica." In Varia bibliographica. Homenaje a José Simón Díaz. Edited by Concepción Casado Lobato, 99-104. Kassel: Reichenberger, 1987.

Fortunio, Torrente. La bolsa en José de la Vega. Confusión de Confusiones-Amsterdam, 1686. Madrid: Libropolis, 1980. 
Fradejas Lebrero, José. “José de la Vega, novelista cortesano." In Los judaizantes en Europa y la literatura castellana del Siglo de Oro. Edited by Fernando Díaz Esteban, 155-65. Madrid: Letrúmero, 1994.

González Ramírez, David. "En el origen de la novella corta del Siglo de Oro: los novellieri en España.” ARBOR Ciencia, Pensamiento y Cultura 756 (2011): 13-28; <http:// arbor.revistas.csic.es/index.php/arbor/article/viewFile/1502/1513>.

Israel, Jonathan. "Een merkwaardig literair werk en de Amsterdamse effectenmarkt in 1688. Joseph Penso de la Vega, Confusión de confusiones." De Zeventiende eeuw 6 (1990): 159-65.

Kellenbenz, Hermann. "Introduction." In Penso de la Vega, Confusion of Confusion. Portions Descriptive of the Amsterdam Stock Exchange. Cambridge, MA: Harvard University Press, 1957.

Kluge, Sofie. Baroque, Allegory, Comedia. The Transfiguration of Tragedy in SeventeenthCentury Spain. Kassel: Reichenberger, 2010.

Maravall, José Antonio. La cultura del Barroco: análisis de una estructura histórica. Barcelona: Ariel, 1975.

Nider, Valentina. “José Penso e l'accademia sefardita 'de los sitibundos' di Lidvorno nella diffusione di un genere oratorio fra Italia e Spagna: Traduzione e limitazione nelle 'Ideas posibles' (1692)." Studi secenteschi 51 (2010): 156-57.

Pagis, Dan. A Secret Sealed. Hebrew Baroque Emblem-Riddles from Italy and Holland. [Hebrew]. Jerusalem: Magnes Press, 1986.

Penso, Josseph. Pardes Shoshanim. Amsterdam: Yosef Atiash, 1668.

Penso, Josseph. Asirei ha-Tikva. Livorno: Santini Presso Carlo Giorgi, 1771.

Penso de la Vega, José. Confusión de confusiones, Ediciones Saetabis, 1977: Confusión de confusiones Diálogos Curiosos entre un Philósopho agudo, un Mercader discreto, y un Accionista erudito descriviendo el negocio de las Acciones, su origen, su ethimología, su realidad, su juego y su enredo, Compuesto por Don Iosseph de la Vega, Que con reverente obsequio lo dedica al Mérito y Curiosidad del muy Ilustre Señor Duarte Nuñez da Costa. Én Amsterdam Año 1688.

Penso de la Vega, José. Rumbos Peligrosos por donde navega con título de Novelas la zozobrante Nave de la Temeridad temiendo los peligrosos Escollos de la Censura. Antwerp, 1683.

Poppenberg, Gerhard. Psyche und Allegorie. Studien zum spanischen auto sacramental von den Anfängen bis zu Calderón. Paderborn: Fink, 2003.

Scholberg, Kenneth R. La poesía religiosa de Miguel de Barrios. Madrid: Ohio State University Press, 1962.

Sombart, Werner. Die Juden und das Wirtschaftsleben. Leipzig: Verlag von Duncker und Humblot, 1911.

Sullivan, Henry W. Calderón in the German Lands and the Low Countries: His Reception and Influence, 1654-1980. Cambridge: Cambridge University Press, 2009.

Wölfflin, Heinrich. Renaissance und Barock: eine Untersuchung über Wesen und Entstehung des Barockstils in Italien. Munich: Bruckmann, 1888. 